Vol. 5(1996): 167-175.

\title{
Feeding whole grain with pelleted diets to growing broiler chickens
}

\author{
Tuomo Kiiskinen \\ Agricultural Research Centre of Finland, Institute of Animal Production, FIN-31600 Jokioinen, Finland
}

\begin{abstract}
In three trials with growing broilers (aged 12-8 days) the proportion of whole grain (WG) was increased step by step up to $30 \%$ (Trial 1) along with commercial starter (S) and grower (G) pellets or up to $40 \%$ (Trial 2) and $50 \%$ (Trial 3) with special balancer (BA) pellets (crude protein $250 \mathrm{~g} / \mathrm{kg}$ ). WG accounted for about $20 \%, 31 \%$ and $38 \%$ of the broilers' total feed intakes, respectively. In Trial 1 , the grain was exclusively wheat $(\mathrm{W})$. In the other trials, also mixtures of wheat and barley (W:B $70: 30,50: 50$ ) were used. Crude protein analyses of feed remains revealed that birds did not to any considerable extent select between pellets and grain. Mixing wheat with $\mathrm{S}$ or $\mathrm{G}$ pellets reduced feed intake significantly $(\mathrm{P}<0.05)$ and, as a consequence, the growth rate decreased by $3-5 \%$. However, the feed efficiency $(\mathrm{FCR})$ of the SW birds was significantly $(\mathrm{P}<0.05)$ better than that of the control and GW birds. In Trial 2, the BAWG treatments reduced feed intake $(\mathrm{P}<0.05)$ and weight gain, but there were no significant differences in FCR. In Trial 3, the growth rate was similar with all the regimens, and birds fed the BAW diet consumed feed less $(\mathrm{P}<0.001)$ but more efficiently $(\mathrm{P}<0.001)$ than those fed the other diets. In each trial, the WG feedings increased markedly (50-90\%) the empty gizzard weight. Fatness of broilers decreased significantly $(\mathrm{P}<0.05)$ when whole wheat was fed with the $\mathrm{S}$ diet (Trial 1) but not so when fed with the BA diet (Trials 2 and 3). The present results suggest that during the growing phase, broiler chickens can be fed efficiently with mixtures of a pelleted starter or a pelleted balancer diet and whole wheat which can partly be replaced by barley.
\end{abstract}

Key words: poultry, balancer diet, growth, feed conversion, fatness, gizzard weight

\section{Introduction}

Industrial complete diets for broiler chickens contain cereals up to $70 \%$. Processing, handling and transport increase markedly the original price of whole grain. Therefore, it seems reasonable to develop feeding regimens which base on the use of whole grain produced on the farm, mixing it with industrial starter or grower pellets. This regimen has become very common, especially in the northern countries. Feeding of whole wheat is started at 7-10 days of age, and the proportion of wheat reaches a level of $25-30 \%$ at the end of the growing period. With this regimen the supply of most nutrients and additives 


\section{AGRICULTURAL AND FOOD SCIENCE IN FINLAND}

\section{Kiiskinen, T.: Feeding whole grain with pelleted diets to growing broiler chickens}

decreases. Therefore the addition of wheat apparently tends to reduce the weight gain of broilers (Chwalibog and Eggum 1986, Petersen 1990, Elwinger et al. 1992, Jensen 1992). If the use of whole wheat is cautious or the nutrient contents of the complete diet is raised, the growth rate is similar to that of the controls (Tiller 1989, Covasa and Forbes 1994, Ristic et al. 1994). Other feeding systems which include the use of whole grain are choice feeding and sequential feeding. These methods base on the use of a special balancer diet which in choice feeding systems is provided with whole grain ad libitum in separate feeders. In sequential feeding time-limited ad libitum access to whole grain alternates with a balancer diet. Choice feeding of broilers has been studied extensively using whole wheat but it has not been applied in practice because there is a risk of imbalanced selection of the components, and the system requires extra equipment. Forbes and Covasa (1995) concluded that birds need a period of learning or adjustment to choice feeding. However, the life of a broiler may be too short for this. According to Cumming (1994), the learning period is 7-10 days for chickens, broiler chicks needing a longer period than layer-type chicks. Sequential feeding could be easier to apply in practice, but research into this regimen has been very limited. The length of the feeding period is important. Rose et al. (1995) reported the highest growth rates in the 8-h periods. Mixtures of crumbled or pelleted concentrates and whole grain have been studied previously but the results were not very encouraging (Kiiskinen 1992). The objective of the present study was to examine feeding of whole grain mixed with a complete diet or with a special balancer diet in order to increase the proportion of grain and to replace part of the wheat with barley.

\section{Material and methods}

Ross broiler chicks were kept in floor pens $\left(4 \mathrm{~m}^{2}\right)$ in a temperature controlled windowless room
Table 1. Feeding regimens in Trial 1.

\begin{tabular}{llllll}
\hline \multicolumn{7}{l}{$\begin{array}{l}\text { Age of bird } \\
\text { days }\end{array}$} & 1 & 2 & 3 & 4 & 5 \\
\hline $1-7$ & S & S & S & S & S \\
$8-11$ & S & S & SW 95:5 & S & S \\
$12-16$ & G & SW 90:10 & SW 90:10 & GW 90:10 & SWP 80:20 \\
$17-21$ & G & SW 85:15 & SW 85:15 & GW 85:15 & SWP 80:20 \\
$22-28$ & G & SW 80:20 & SW 80:20 & GW 80:20 & SWP 80:20 \\
$29-35$ & G & SW 75:25 & SW 75:25 & GW 75:25 & SWP 80:20 \\
$36-38$ & F & SW 70:30 & SW 70:30 & GW 70:30 & SWP 80:20 \\
\hline
\end{tabular}

$\mathrm{S}=$ starter, $\mathrm{G}=$ grower, $\mathrm{F}=$ finisher, $\mathrm{SW}=$ mixture of a pelleted starter and whole wheat, $\mathrm{GW}=$ mixture of a pelleted grower and whole wheat, $\mathrm{SWP}=$ pelleted mixture of a starter and wheat meal

under a daily light period of $23 \mathrm{~h}$. Peat was used as litter material. Each pen contained 60 sexed birds $\left(15 / \mathrm{m}^{2}\right)$ which had free access to feed and water. Half of the pens contained male birds and the other half females. The treatments were allotted between the successive pens containing the same sex. Three trials were conducted. Trial 1 included five treatment groups with the feeding regimens shown in Table 1 . The industrial complete diets which were used either as the only feed (Group 1, control) or mixed with whole wheat (Groups 2-4) were based on soybean meal, pea meal, wheat, barley and oats. According to the declarations, the starter diet contained crude protein (CP) $23.0 \%$, metabolizable energy (ME) $12.0 \mathrm{MJ} / \mathrm{kg}$, lysine $1.4 \%$ and methionine $0.6 \%$. The corresponding values for the grower diet were $20.0 \%, 12.5 \mathrm{MJ} / \mathrm{kg}, 1.2 \%$ and $0.5 \%$. All birds, excluding those of group 3 , were given the same crumbled starter diet (S) up to the age of 11 days. Group 3 was fed with the starter diet up to the age of one week. Thereafter groups 2 and 3 were given a mixture of pelleted starter diet and whole wheat (SW) and group 4 a mixture of grower pellets and whole wheat (GW). The proportion of whole wheat was gradually increased up to $30 \%$ (Table 1). Group 5 served, in fact, as a second control which was given a pelleted mixture of the starter diet and ground wheat in a proportion of 80:20 (SWP). 


\section{AGRICULTURAL AND FOOD SCIENCE IN FINLAND}

Vol. 5 (1996): 167-175.

In Trial 2, all birds were fed the same industrial crumbled starter diet during the first 11 days. Thereafter the four treatment groups were fed according to the following plan:

Group 1 A pelleted grower diet on days 12-37 (control)

Group 2 Mixtures of pelleted balancer diet (BA) and whole wheat $(\mathrm{W})$ in the following proportions:

BA:W days 12-18 80:20 days 19-28 70:30 days 29-37 60:40

Group 3 BA+WB1 mixture of whole wheat $(70 \%)$ and barley (30\%) as BA:W

Group 4 BA+WB2 (W:B 50:50) as BA:W

In Trial 3, the birds were fed the same pelleted starter diet for the first 11 days. The grower diets for the three treatment groups were as follows:

Group 1 A pelleted grower diet on days 12-38 (control) Group $2 \mathrm{BA}+\mathrm{W}$ in the following proportions:

$\begin{array}{ll}\text { days 12-18 } & 70: 30 \\ \text { days 19-29 } & 60: 40 \\ \text { days 30-38 } & 50: 50\end{array}$

Group 3 BA+WB2 (50:50) in the same proportions as BA:W

The pelleted starter, grower and balancer diets were manufactured in the feed mill of the Agricultural Research Centre of Finland, and their compositions are shown in Table 2.

The number of replicates (pens) for a treatment was 6,8 and 12 in Trials 1,2 and 3, respectively. The live weight of chicks was measured as a total weight per pen at one day, 11 days and 37-38 days of age. Feed consumption was measured between the weighings. Total slaughter weight and mortality per replicate were recorded. Abdominal fat pad, including gizzard fat and gizzard, was removed and weighed for 24 female birds per treatment in Trial 1 , for $16 \mathrm{fe}$ males per treatment in Trial 2 and for 20 male birds per treatment in Trial 3, excluding group 3 in Trial 1. In addition, six carcasses ( 3 males, 3 females) per treatment (1,2 and 4) in Trial 1 were taken in the slaughter house for determining the fat content of thigh and breast meat. Subcutaneous fat was included in the meat samples. The fat content of the meat samples was determined by eluting the fat with dichloromethane-meta-
Table 2. Composition of the experimental diets in Trials 2 and 3.

\begin{tabular}{lrrrrrr}
\hline Ingredients g/kg & \multicolumn{2}{c}{ Trial 2 } & & \multicolumn{2}{c}{ Trial 3 } \\
\cline { 2 - 3 } \cline { 5 - 6 } \cline { 5 - 6 } & Grower & Balancer & & Grower & Balancer \\
\hline Fish meal & 40 & 60 & & - & - \\
Soybean meal & 210 & 310 & & 270 & 460 \\
Wheat & 300 & 100 & & 300 & 230 \\
Barley & 300 & 320 & & 300 & 220 \\
Oats & 92 & 130 & & 70 & - \\
Plant oil & 30 & 41 & & 30 & 40 \\
Limestone & 10 & 14 & & 9 & 13 \\
Dicalc.phosphate & 10 & 14 & & 14 & 24 \\
Salt & 3 & 4 & & 3 & 5 \\
Premixes & 5 & 7 & & 4 & 8 \\
Methionine add. & 0.5 & 0.7 & & 0.8 & 1.5 \\
Calculated & & & & & & \\
ME MJ/kg & 12.0 & 11.8 & & 11.8 & 11.4 \\
Crude protein g/kg & 200 & 240 & & 200 & 260 \\
Ca & 8.8 & 12.2 & & 8.1 & 12.7 \\
Pavailable & $\mathrm{g} / \mathrm{kg}$ & 4.0 & 5.3 & & 4.0 & 5.9 \\
Methionine & $\mathrm{g} / \mathrm{kg}$ & 4.2 & 5.1 & & 4.0 & 5.7 \\
Lysine & $\mathrm{g} / \mathrm{kg}$ & 10.9 & 14.1 & & 10.3 & 15.3 \\
\hline
\end{tabular}

nol according to the method of Maxwell et al. (1980). At the end of Trial 2, litter samples near the feeders were taken from six pens per treatment for dry matter determination. In statistical analysis the analysis of variance was applied using a SPSS program. The comparisons between treatments were performed using Tukey's test (Steel and Torrie 1960).

\section{Results and discussion}

The analyzed crude protein (CP) content for the starter and grower diets of Trial 1 were 225 and $204 \mathrm{~g} / \mathrm{kg}$, respectively (Table 3). The CP of the corresponding whole wheat containing diets decreased to 192 (SW) and $181 \mathrm{~g} / \mathrm{kg}(\mathrm{GW})$ at the end of the growing period. According to the $\mathrm{CP}$ analysis of feed remains, birds did not select between pellets and whole wheat. In Trial 2, the analyzed CP for the grower was $209 \mathrm{~g} / \mathrm{kg}$ and that of the balancer $248 \mathrm{~g} / \mathrm{kg}$. In the BAW diets 


\section{AGRICULTURAL AND FOOD SCIENCE IN FINLAND}

Kiiskinen, T.: Feeding whole grain with pelleted diets to growing broiler chickens

Table 3. Analysed crude protein (CP) content in the diets, grain and feed remains (in parentheses).

\begin{tabular}{|c|c|c|c|}
\hline Diet (grain) & $\frac{\text { Trial } 1}{\mathrm{CP} \mathrm{g} \mathrm{kg}^{1)}}$ & $\frac{\text { Trial } 2}{\mathrm{CP} \mathrm{g/ \textrm {kg } ^ { 1 ) }}}$ & $\frac{\text { Trial } 3}{\mathrm{CP} / \mathrm{kg}^{1)}}$ \\
\hline Starter (S) & 225 & 260 & 222 \\
\hline Grower (G) & 204 & 209 & 202 \\
\hline Balancer (BA) & - & 248 & 252 \\
\hline Wheat (W) & 125 & 126 & 124 \\
\hline Barley (B) & - & 140 & 126 \\
\hline S:W proportion & & BA:W & BA:W \\
\hline $90: 10$ & $215(220)$ & $80: 20 \quad 229(231)$ & $70: 30 \quad 225$ \\
\hline $80: 20$ & 207 (206) & $212(220)$ & $60: 40$ \\
\hline $70: 30$ & $192(197)$ & $60: 40 \quad 198(211)$ & $50: 50 \quad 189$ \\
\hline \multicolumn{2}{|l|}{ G:W proportion } & \multicolumn{2}{|l|}{ BA:WB1 (W:B 70:30) } \\
\hline $90: 10$ & 194 (196) & $80: 20 \quad 223(232)$ & - \\
\hline $80: 20$ & $188(185)$ & $70: 30 \quad 214(225)$ & - \\
\hline \multirow[t]{5}{*}{$70: 30$} & $181(184)$ & $60: 40 \quad 198(214)$ & - \\
\hline & & BA:WB2 (W:B 50:50) & BA:WB2 \\
\hline & & $80: 20 \quad 220(230)$ & $70: 30 \quad 220$ \\
\hline & & $70: 30 \quad 211(225)$ & $60: 40 \quad 205$ \\
\hline & & $60: 40 \quad 204(217)$ & $50: 50 \quad 189$ \\
\hline
\end{tabular}

1) $88 \%$ dry matter

the CP decreased to $198-204 \mathrm{~g} / \mathrm{kg}$ at the end of the trial. The birds apparently ate slightly more grain than BA pellets because the $\mathrm{CP}$ for feed remains was $10-15 \mathrm{~g} / \mathrm{kg}$ higher than that of the corresponding diet. The proportion of the remains was $10-15 \%$ of the given feed and so the changes in the supply of nutrients were small and insignificant. The grower and the balancer diets of Trial 3 contained CP 202 and $252 \mathrm{~g} / \mathrm{kg}$, respectively. The CP content of the BAWG diets dropped to $189 \mathrm{~g} / \mathrm{kg}$ during the last week.

The calculated proportion of whole wheat was around $20 \%$ of the total feed consumption (Trial 1). Those birds which were given the SW feeding regimens consumed feed $7 \mathrm{~g}$ less per day $(\mathrm{P}<0.05)$ than the control birds (Table 4). Also groups $4(\mathrm{GW})$ and 5(SWP) which were fed a pelleted mixture of the starter and wheat meal ate less $(\mathrm{P}<0.05)$ than the control group. This was apparently the main reason for the $3-5 \%$ lower growth rates of the broilers given wheat in the diet. Groups 3 and 4 differed significantly $(\mathrm{P}<0.05)$ from the control group.

However, the weight gain of the wheat - fed broilers, can be regarded as satisfactory. Also the slaughter weights of the wheat - fed groups decreased by $1-4 \%$ and there was a significant $(\mathrm{P}<0.05)$ difference between the GW and the control groups. Compared with the control and the GW feeding treatments, each SW feeding regimen improved significantly $(\mathrm{P}<0.05)$ the feed efficiency (FCR) and the FCR of group 2 was significantly $(\mathrm{P}<0.05)$ better than that of group 5 which was given ground wheat in the pellets. This implies that whole wheat feeding has a beneficial effect on the digestion, apparently due to the enlargement of the gizzard.

It seems that better results can be achieved when whole wheat is used with the starter pellets than with the grower pellets. This is understandable, because the starters contain higher concentrations of several nutrients (protein, minerals, vitamins) than the growers and the effect of dilution with whole wheat is not so marked. This is clearly shown in the calculated total intakes per bird (Table 5). The CP consumption of the GW birds was $570 \mathrm{~g}$ and that of the SW birds $607-608 \mathrm{~g}$. The uptake of methionine was $13.4 \mathrm{~g}$ 
Vol. 5 (1996): 167-175.

Table 4. Effects of whole wheat feeding in Trial 1.

\begin{tabular}{|c|c|c|c|c|c|c|c|}
\hline $\begin{array}{l}\text { Group } \\
\text { Grower diet }{ }^{1)}\end{array}$ & $\begin{array}{c}1 \\
\text { Control }\end{array}$ & $\begin{array}{c}2 \\
\text { SW }\end{array}$ & $\begin{array}{c}3 \\
\text { SW }\end{array}$ & $\begin{array}{c}4 \\
\text { GW }\end{array}$ & $\begin{array}{c}5 \\
\text { SWP }\end{array}$ & SEM $^{2)}$ & Significance ${ }^{2)}$ \\
\hline Final body weight & $2022^{b}$ & $1972^{a b}$ & $1959^{\mathrm{a}}$ & $1939^{a}$ & $1988^{\mathrm{ab}}$ & 25.8 & $* *$ \\
\hline Weight gain $12-37 \mathrm{~d}$ & $1725^{b}$ & $1678^{\mathrm{ab}}$ & $1657^{a}$ & $1639^{a}$ & $1688^{\mathrm{ab}}$ & 24.5 & $* *$ \\
\hline Slaughter weight g & $1325^{b}$ & $1294^{\mathrm{ab}}$ & $1300^{\mathrm{ab}}$ & $1272^{\mathrm{a}}$ & $1306^{\mathrm{ab}}$ & 18.3 & $* *$ \\
\hline \multicolumn{8}{|l|}{ Feed intake $12-37 \mathrm{~d}$} \\
\hline $\mathrm{g} / \mathrm{bird} / \mathrm{d}$ & $115^{\mathrm{c}}$ & $108^{a}$ & $108^{a}$ & $110^{\mathrm{ab}}$ & $112^{\mathrm{b}}$ & 1.1 & $* * *$ \\
\hline \multirow{2}{*}{$\begin{array}{ll}\text { FCR } & 12-37 d^{3)} \\
& 1-37 d\end{array}$} & $1.89^{\mathrm{d}}$ & $1.83^{\mathrm{a}}$ & $1.84^{\mathrm{ab}}$ & $1.88^{\text {cd }}$ & $1.87^{\text {bed }}$ & 0.010 & $* * *$ \\
\hline & $1.80^{d}$ & $1.74^{a}$ & $1.74^{\mathrm{ab}}$ & $1.78^{\mathrm{cd}}$ & $1.78^{\text {bed }}$ & 0.009 & $* * *$ \\
\hline $\mathrm{kg}$ feed/kg slaughter weight & $2.73^{\mathrm{c}}$ & $2.63^{\mathrm{ab}}$ & $2.61^{\mathrm{a}}$ & $2.71^{\mathrm{c}}$ & $2.69^{b c}$ & 0.013 & $* * *$ \\
\hline Mortality \% (12-37 d) & 3.8 & 3.6 & 2.7 & 2.5 & 3.1 & 0.37 & NS \\
\hline Gizzard weight g (females) & $18.9^{a}$ & $26.9^{b}$ & - & $27.5^{b}$ & $17.2^{\mathrm{a}}$ & 0.52 & $* * *$ \\
\hline$\%$ of live wgt & $1.10^{\mathrm{a}}$ & $1.64^{b}$ & - & $1.66^{\mathrm{b}}$ & $0.98^{a}$ & 0.033 & $* * *$ \\
\hline Abdominal fat $\mathrm{g}$ (females) & $47.1^{b}$ & $37.6^{\mathrm{a}}$ & - & $45.0^{b}$ & $46.7^{\mathrm{b}}$ & 1.12 & $*$ \\
\hline$\%$ of live wgt & $2.69^{b}$ & $2.26^{\mathrm{a}}$ & - & $2.71^{b}$ & $2.66^{\mathrm{ab}}$ & 0.058 & $*$ \\
\hline \multicolumn{8}{|l|}{ Carcass fat $\%$} \\
\hline Thigh males & $9.38^{\mathrm{b}}$ & $7.33^{\mathrm{a}}$ & - & $9.82^{\mathrm{b}}$ & - & 0.478 & $*$ \\
\hline females & 10.93 & 10.53 & - & 13.24 & - & 0.621 & NS \\
\hline average & $10.16^{\mathrm{b}}$ & $8.93^{\mathrm{a}}$ & - & $11.53^{b}$ & - & 0.505 & $*$ \\
\hline Breast males & 4.10 & 2.99 & - & 4.44 & - & 0.283 & NS $(\mathrm{P}=0.06)$ \\
\hline females & 4.69 & 4.82 & - & 5.74 & - & 0.224 & NS \\
\hline average & $4.40^{\mathrm{ab}}$ & $3.91^{\mathrm{a}}$ & - & $5.09^{b}$ & - & 0.232 & $*$ \\
\hline
\end{tabular}

1) $\mathrm{SW}=$ starter + whole wheat, $\mathrm{GW}=$ grower + whole wheat, SWP $=$ pelleted starter $(80 \%)+$ wheat meal $(20 \%)$

2) $\mathrm{SEM}=$ standard error of mean, ${ }^{*} \mathrm{P}<0.05$, ${ }^{* *} \mathrm{P}<0.01$, ${ }^{* * *} \mathrm{P}<0.001$, NS $=$ non-sinificant

3) $\mathrm{FCR}=$ feed conversion ratio

a-d Means marked with a common letter do not differ at $\mathrm{P}<0.05$.

and $15.6 \mathrm{~g}$ and that of lysine $31.4 \mathrm{~g}$ and 35.6-35.7 g, respectively. Concerning reduced growth rate, the present results are in agreement with earlier studies (Chwalibog and Eggum 1986, Petersen 1990, Elwinger et al. 1992, Jensen 1992). Elwinger et al. (1992) also reported lower feed intake and FCR when a pelleted complete diet contained on average $20 \%$ whole wheat. The similar results of treatments 2 and 3 suggest that whole wheat feeding can be started at the age of one week.

In Trial 2, the proportion of WG was around $31 \%$ of the total feed intake. Even in this trial the feed intake was significantly $(\mathrm{P}<0.05)$ reduced when whole grain was fed with the balancer. The reduction was 5-6\%. This resulted in $3.5-4 \%$ lower weight gain during the period of 12-37 days. However, only group 4 (BAWB2), which was given the highest proportion of bar- ley $(50 \%)$ differed significantly $(\mathrm{P}<0.05)$ from the control group. In this trial, feed intakes and growth rates were poorer than in Trial 1. The calculated supplies of ME, CP and amino acids per bird were also clearly lower in Trial 2 (Table 5). The BAWG birds received less CP and amino acids than the control birds, which explains the differences in weight gain. FCR was non-significantly lower in the whole grain - fed groups, and feed consumption per kilo slaughter weight decreased by $4 \%(\mathrm{P}<0.05)$ in groups $2(\mathrm{BAW})$ and 4 (BAWB2) compared with the control group. Rose et al. (1995) used in their sequentical feeding study balancer - whole wheat mixtures (loose-mix feeding) as a control. They found that the broilers given the loose-mix feed had growth rates and feed intakes similar to those given complete diets.

In Trial 3, the final body weights and weight 


\section{AGRICULTURAL AND FOOD SCIENCE IN FINLAND}

Kiiskinen, T.: Feeding whole grain with pelleted diets to growing broiler chickens

Table 5. Calculated consumption of ME, CP and amino acids during the growing period.

\begin{tabular}{lcccc}
\hline & $\begin{array}{c}\text { ME } \\
\text { MJ/bird }\end{array}$ & $\begin{array}{c}\text { CP } \\
\text { g/bird }\end{array}$ & $\begin{array}{c}\text { Methionine } \\
\text { g/bird }\end{array}$ & $\begin{array}{c}\text { Lysine } \\
\text { g/bird }\end{array}$ \\
\hline Trial 1 & & & & \\
Control & 40.4 & 649 & 16.2 & 38.8 \\
SW & 36.8 & 608 & 15.6 & 35.7 \\
SW & 36.7 & 607 & 15.6 & 35.6 \\
GW & 38.5 & 570 & 13.4 & 31.4 \\
SWP & 39.3 & 618 & 16.3 & 37.4 \\
Trial 2 & & & & \\
Control & 32.8 & 576 & 11.5 & 29.8 \\
BAW & 31.2 & 550 & 10.4 & 27.2 \\
BAWB1 & 30.8 & 550 & 10.5 & 27.5 \\
BAWB2 & 30.8 & 556 & 10.6 & 28.0 \\
Trial 3 & & & & \\
Control & 38.4 & 656 & 13.0 & 33.5 \\
BAW & 37.3 & 626 & 13.0 & 32.1 \\
BAWB2 & 37.8 & 658 & 13.6 & 34.4 \\
\hline
\end{tabular}

$\mathrm{SW}=$ starter + whole wheat

$\mathrm{GW}=$ grower + whole wheat

SWP $=$ pelleted mixture of starter $(80 \%)$ and wheat meal (20\%)

BAW $=$ balancer + whole wheat

BAWB1 = balancer + whole grain (W:B 70:30)

$\mathrm{BAWB} 2$ = balancer 0 whole grain (W:B 50:50)

gains during the growing period (12-38 days) were very similar for all treatments. However, the BAW birds consumed feed less $(\mathrm{P}<0.05)$ and more efficiently $(\mathrm{P}<0.05)$ than those on the other regimens. Reduced feed intake and lowered FCR of the BAW group was obviously due to the higher dietary energy content, at least compared with the diet containing whole barley. Intakes of ME, CP and amino acids were comparatively similar, which is in agreement with the growth results (Table 5). Feeding whole barley with the balancer did not affect feed intake or FCR compared with the control diet. The good growth results with barley may seem exceptional because barley contains more fibre and less energy than wheat, reducing the growth rate and feed efficiency (Jeroch and Dänicke 1995). The BAWB2 diet contained, however, wheat and barley in the same proportion as the control diet, and older broilers tolerate barley better than young ones. This is explained by an adaptation of the microflora in the gastrointestinal tract to produce entzymes ( $\beta$-glucanases) which decompose antinutritive carbohydrates, $\beta$-glucanes. The proportion of WG was $38 \%$ of the total feed consumption.

No significant treatment $\times$ sex interactions concerning growth rate, feed intake or FCR were found in the trials.

There were no significant differences in any of the trials between the treatments in mortality during the experimental period. As expected, whole grain either with the complete diets or with the balancers increased significantly $(\mathrm{P}<0.05)$ the empty gizzard weight. On average, the absolute weight of the gizzard was $18 \mathrm{~g}$ in the birds fed complete diets and $27 \mathrm{~g}$ in those fed whole wheat (Table 4). Expressed as a percentage of live weight, the values were $1.0 \%$ and $1.65 \%$, respectively. In Trials 2 (Table 6 ) and 3 (Table 7), the corresponding values for the control birds were $19-20 \mathrm{~g}$ or $0.9-1.3 \%$ and for those fed whole grain $28-36 \mathrm{~g}$ or $1.7-2.1 \%$. This shows that whole grain kept the gizzard working. This can have a beneficial effect on the bacterial population in the intestine, and Cumming (1992) suggested that an active gizzard may contribute to the development of resistance against coccidiosis in the chicken. The strengthened gizzard may have improved the FCR of some whole grain-fed group. McIntosh et al. (1962) reported that unground wheat yields about $5-10 \%$ more energy. This may be due in part to the fact that the finely ground and pelleted complete diets are much faster removed from the gizzard than whole grain, possibly resulting in incomplete absorption of some nutrients.

Using whole wheat with the starter pellets reduced the abdominal fat of female birds from 47 to $38 \mathrm{~g}$ or, given as a percentage of live weight, from $2.7 \%$ to $2.3 \%$ ( $\mathrm{P}<0.05$, Table 4$)$. The other treatments did not affect significantly the abdominal fat content compared with the control. The fat content of the thigh and breast was also decreased in the carcasses of the SW birds. The difference from the control was significant $(\mathrm{P}<0.05)$ in the thigh and this was ob- 
Vol. 5 (1996): 167-175.

Table 6. Effects of mixtures of a balancer and whole grain in Trial 2.

\begin{tabular}{lccccrl}
\hline $\begin{array}{l}\text { Group } \\
\text { Grower diet }{ }^{1)}\end{array}$ & $\begin{array}{c}1 \\
\text { Control }\end{array}$ & $\begin{array}{c}2 \\
\text { BAW }\end{array}$ & $\begin{array}{c}3 \\
\text { BAWB1 }\end{array}$ & $\begin{array}{c}4 \\
\text { BAWB2 }\end{array}$ & SEM $^{2)}$ & Significance $^{2)}$ \\
\hline Final body weight g & $1806^{\mathrm{b}}$ & $1754^{\mathrm{ab}}$ & $1750^{\mathrm{ab}}$ & $1733^{\mathrm{b}}$ & 24.9 & $*$ \\
Weight gain g (12-37 d) & $1545^{\mathrm{b}}$ & $1491^{\mathrm{ab}}$ & $1488^{\mathrm{ab}}$ & $1481^{\mathrm{a}}$ & 23.4 & $* *$ \\
Slaughter wgt g & $1168^{\mathrm{b}}$ & $1139^{\mathrm{ab}}$ & $1131^{\mathrm{ab}}$ & $1117^{\mathrm{a}}$ & 16.8 & $*$ \\
Feed intake (12-37 d) & & & & & & \\
$\quad$ g/bird/d & $105.1^{\mathrm{b}}$ & $99.5^{\mathrm{a}}$ & $99.1^{\mathrm{a}}$ & $99.6^{\mathrm{a}}$ & 1.15 & $* *$ \\
FCR 12-37 d & 1.79 & 1.76 & 1.75 & 1.76 & 0.011 & NS \\
$\quad 1-37$ " & 1.70 & 1.68 & 1.67 & 1.68 & 0.009 & NS \\
kg feed/kg slaughter wgt & $2.68^{\mathrm{b}}$ & $2.58^{\mathrm{a}}$ & $2.62^{\mathrm{ab}}$ & $2.58^{\mathrm{a}}$ & 0.015 & $*$ \\
Mortality \% (12-37 d) & 6.1 & 4.2 & 5.7 & 2.6 & 0.70 & NS \\
Gizzard weight g (females) & $19.9^{\mathrm{a}}$ & $29.0^{\mathrm{b}}$ & $28.4^{\mathrm{b}}$ & $30.7^{\mathrm{b}}$ & 0.69 & $* * *$ \\
$\quad \%$ & $1.28^{\mathrm{a}}$ & $1.95^{\mathrm{b}}$ & $1.90^{\mathrm{b}}$ & $2.05^{\mathrm{b}}$ & 0.046 & $* * *$ \\
Abdominal fat g (females) & 31.3 & 28.8 & 28.4 & 28.0 & 1.11 & NS \\
$\quad \%$ & 2.01 & 1.95 & 1.87 & 1.84 & 0.064 & NS \\
Litter dry matter \% & 36.3 & 34.5 & 34.8 & 35.2 & 0.33 & NS \\
\hline
\end{tabular}

1) $\mathrm{BAW}=$ balancer + whole wheat, $\mathrm{BAWB} 1=$ balancer + whole grain (wheat: barley 70:30), BAWB2 = balancer + whole grain (W:B 50:50))

2) see Table 4

3) $\mathrm{FCR}=$ feed conversion ratio

$\stackrel{a b}{a}$ see Table 4

Table 7. Effects of mixtures of a balancer and whole grain in Trial 3.

\begin{tabular}{|c|c|c|c|c|c|}
\hline $\begin{array}{l}\text { Group } \\
\text { Grower diet }{ }^{1)}\end{array}$ & $\begin{array}{c}1 \\
\text { Control }\end{array}$ & $\begin{array}{c}2 \\
\text { BAW }\end{array}$ & $\begin{array}{c}3 \\
\text { BAWB2 }\end{array}$ & SEM $^{2)}$ & Significance $^{2)}$ \\
\hline Final body weight & 1941 & 1942 & 1942 & 25.5 & NS \\
\hline Weight gain g (12-38 d) & 1610 & 1619 & 1613 & 24.2 & NS \\
\hline Slaughter weight g & 1288 & 1274 & 1268 & 16.9 & NS \\
\hline \multicolumn{6}{|l|}{ Feed intake (12-38 d) } \\
\hline $\mathrm{g} / \mathrm{bird} / \mathrm{d}$ & $120^{\mathrm{a}}$ & $116^{\mathrm{b}}$ & $120^{\mathrm{a}}$ & 1.2 & $* * *$ \\
\hline \multirow{2}{*}{$\begin{array}{ll}\text { FCR } & 12-38 \mathrm{~d} \\
& 1-38 \mathrm{~d}\end{array}$} & $2.04^{a}$ & $1.94^{\mathrm{b}}$ & $2.03^{a}$ & 0.012 & $* * *$ \\
\hline & $1.91^{\mathrm{a}}$ & $1.84^{\mathrm{b}}$ & $1.91^{\mathrm{a}}$ & 0.009 & $* * *$ \\
\hline $\mathrm{kg} \mathrm{feed} / \mathrm{kg}$ slaughter wgt & $2.87^{a}$ & $2.78^{b}$ & $2.88^{a}$ & 0.009 & $* * *$ \\
\hline Mortality \% & 5.1 & 4.0 & 3.8 & 0.44 & NS \\
\hline Gizzard weight g (males) & $19.4^{\mathrm{a}}$ & $33.6^{b}$ & $36.0^{b}$ & 1.06 & *** \\
\hline$\%$ & $0.94^{a}$ & $1.60^{b}$ & $1.78^{\mathrm{c}}$ & 0.052 & $* * *$ \\
\hline Abdominal fat $g$ (males) & 40.4 & 39.3 & 35.3 & 1.21 & NS \\
\hline$\%$ & 1.95 & 1.87 & 1.74 & 0.055 & NS \\
\hline
\end{tabular}

1) $\mathrm{BAW}=$ balancer + whole wheat, $\mathrm{BAWB} 2=$ balancer + whole grain $(\mathrm{W}: \mathrm{B}$ 50:50)

2) see Table 4

3) $\mathrm{FCR}=$ feed conversion ratio

a-c see Table 4

served especially among male broilers. Inversely, feeding the GW diet increased but not significantly the fat content of the thigh and breast. The difference $(\mathrm{P}<0.05)$ in fatness between the SW and GW birds can be explained by the difference in protein: energy ratio of the diets. Appar- 


\section{AGRICULTURAL AND FOOD SCIENCE IN FINLAND}

\section{Kiiskinen, T.: Feeding whole grain with pelleted diets to growing broiler chickens}

ently for the same reason, the SW broilers contained less fat than the controls. In trials 2 and 3 there was a tendency towards lower abdominal fat in the whole grain-fed broilers but the differences were not significant. Tiller (1989) and Ristic et al. (1994) did not find any significant effect on the abdominal fat when using mixtures of a complete diet or a balancer and whole wheat. In an earlier study (Kiiskinen 1992), the fatness of broilers given mixtures of a concentrate (CP $40-43 \%)$ and whole wheat, decreased significantly, but the growth rate, too, was considerably reduced. Litter moisture seemed non-significantly to increase in the whole grain fed groups in Trial 2 (Table 6). This has been reported also in earlier studies (Elwinger et al. 1992, Kiiskinen 1992, Rose et al. 1995).

In conclusion, the pelleted starter diets are more suitable than the grower pellets for mixing with whole wheat. Feeding of whole wheat can be started at the age of one week. A whole grain content of more than $20 \%$ of total feed intake will yield a satisfactory weight gain and efficient feed conversion if a suitable pelleted balancer diet is used. Part of the wheat can be replaced with barley.

\section{References}

Chwalibog, A. \& Eggum, B.O. 1986. Effekten af ekstra hvede i foderblandinger til slagtekyllinger. (Effects of extra wheat in the broiler diets). Landbrugsministeriet, Denmark. Statens Husdyrbrugsforsøg. 624. Meddelelse. 4 p. Covasa, M. \& Forbes, J.M. 1994. Performance of broiler chickens as affected by split time feeding and wheatdiluted diet. Proceedings of the $9^{\text {th }}$ European Poultry Conference vol. 1, Glasgow, UK. p. 457-458.

Cumming, R.B. 1992. The biological control of coccidiosis by choice feeding. Proceedings of the XIX World's Poultry Congress vol. 2, Amsterdam, The Netherlands. p. 425-428.

- 1994. Opportunities for whole grain feeding. Proceedings of the $29^{\text {th }}$ European Poultry Conference vol. 2, Glasgow, UK. p. 219-222.

Elwinger, K., Schneitz, C., Berndtson, E., Fossum, O., Teglöf, B., \& Engström, B. 1992. Factors affecting the incidence of necrotic enteritis, caecal carriage of Clostridium perfringens and bird performance of broiler chicks. Acta Veterinaria Scandinavica 33: 369-378.

Forbes, J.M. \& Covasa, M. 1995. Application of diet selection by poultry with particular reference to whole cereals. World's Poultry Science Journal 51: 149-165.

Jensen, J. F. 1992. Majs - eller hvede - baserede forderblandinger til slagtekyllinger. (Corn or wheat based diets for broiler chickens). Landbrugsministeriet, Denmark. Statens Husdyrbrugsforsøg. 836. Meddelelse. 7 p. Jeroch, H. \& Dänicke, S. 1995. Barley in poultry feeding: a review. World's Poultry Science Journal 51: 271291.
Kiiskinen, T. 1992. Tilalla tuotetun rehun kâyttömahdollisuudet broilerituotannossa. (Possibilities to use feed produced on a farm in broiler production). Siipikarja 74 : 137-139, 162-163.

Maxwell, R.J., Marmer, W.N., Zubillaga, M.P. \& Dalickas, G.A. 1980. Determination of total fat in meat and meat products by a rapid column method. Journal of the Association of Official Analytical Chemistry 63:600-603. McIntosh, J.I., Slinger, S.J., Sibbald, I.R. \& Ashton, G.C. 1962. Factors affecting the metabolizable energy content of poultry feeds. Poultry Science 41: 445-456.

Petersen, V. E. 1990. Hel hvede til slagtekyllinger. (Whole wheat for broiler chickens). Landbrugsministeriet, Denmark. Statens Husdyrbrugsforsøg. 781. Meddelelse. 4 p. Ristic, M., Krenzer, M., Roth, F.X. \& Kirchgessner, M. 1994. Mastleistung. Schlachtkörperwert und Fleischqualităt von Broilern bei Anwendung unterschiedlicher Varianten der Zufütterung von ganzen Weizenkörnern. Archiv für Geflügelkunde 58: 8-17.

Rose, S.P., Fielden, M., Foote, W.R. \& Gardin, P. 1995. Sequential feeding of whole wheat to growing broiler chickens. British Poultry Science 36: 97-111.

Steel, R.D. \& Torrie, J.H. 1960. Principles and Procedures of Statistics. Mc Graw-Hill Book Company, New York. $481 \mathrm{p}$.

Tiller, H. 1989. Der Zusatz von Weizenkörnern zu Broilermast-Allein-oder Ergänzungsfuttern - Einflüsse auf Leistung und Fettansatz. Archiv für Geflügelkunde 53: 4446. 
Vol. 5 (1996): 167-175.

\author{
SELOSTUS \\ Kokojyväviljan syöttäminen broilereille rakeisen rehun seassa \\ Tuomo Kiiskinen \\ Maatalouden tutkimuskeskus
}

Tutkimuksessa selvitettiin kokojyväviljan käytön vaikutuksia ja mahdollisuuksia broilerituotannossa. Broilereille annettiin 1-1,5 viikon iästä lähtien rehua, johon lisättiin asteittain jyviä. Kokeessa 1 käytettiin rakeisia täysrehuja ja kokeissa 2 ja 3 erityisiä täydennysrehuja, jotka sisälsivät $25 \%$ raakavalkuaista. Kokeen lopussa jyvien määrä oli suurimmillaan täysrehuun sekoitettuna $30 \%$ ja täydennysrehujen kanssa 40 ja $50 \%$. Jyvien osuus rehun kokonaiskulutuksesta oli vastaavasti $20 \%, 31 \%$ ja $38 \%$. Kokeessa 1 käytettiin vehnää ja muissa kokeissa vehnän lisäksi myös vehnä-ohraseoksia (70:30 ja 50:50). Kaikkiaan kokeissa oli 5880 Ross-poikasta, joiden kasvatusaika oli 37-38 vrk. Rehutähteiden raakavalkuaisanalyysien perusteella linnut eivät merkittävästi valinneet rakeiden ja jyvien välillä. Vehnänjyvien sekoittaminen rakeiseen täysrehuun vähensi rehunkulutusta ja sen seurauksena kasvua 3-5 \%. Rakeista alku- eli starttirehua käytettäessä jyvien kanssa rehun hyväk- sikäyttö oli merkitsevästi parempi kuin vertailurehulla (täysrehu) tai kasvatusrehu-jyväruokinnalla. Tulosten perusteella varovainen jyvien lisäys rakeiseen alkurehuun voidaan aloittaa jo viikon ikäisille linnuille. Myös kokeessa 2 jyvien syöttäminen rakeisen täydennysrehun kanssa vähensi rehunkulutusta ja kasvua, mutta rehuhyötysuhteessa ei ollut merkitseviä eroja. Sen sijaan kokeessa 3 täydennysrehu-jyväruokinta tuotti vähintään yhtä hyvän tuloksen kuin vertailurehu ja vehnänjyviä käytettäessä rehun hyväksikäyttö oli jopa parempi kuin muissa ryhmissä. Jokaisessa kokeessa jyvien syöttäminen lisäsi huomattavasti (50-90 \%) tyhjän lihasmahan painoa. Kokeessa 1 broilerien rasvaisuus väheni merkitsevästi alkurehu-vehnäryhmässä vertailu- ja kasvatusrehu-vehnäryhmään verrattuna. Tulosten perusteella broilerituotannossakin voidaan käyttää runsaasti kokojyväviljaa sopivan rakeisen täydennysrehun kanssa sekoitettuna. Vehnästä voidaan korvata ohralla 30-50 \%. 